\title{
Effects of Temperature on Growth and Biochemical Composition of Larval Winter Flounder Pseudopleuronectes americanus*
}

\author{
Lawrence J. Buckley \\ National Oceanic and Atmospheric Administration, National Marine Fisheries Service, Northeast Fisheries Center, \\ Narragansett Laboratory, Narragansett, Rhode Island 02882 1199, USA
}

\begin{abstract}
Winter flounder (Pseudopleuronectes americanus) eggs fertilized at $2{ }^{\circ} \mathrm{C}$ were incubated at $2,5,7$, and $10^{\circ} \mathrm{C}$. At hatching the larvae produced at all 4 temperatures were similar in standard length, protein, RNA and DNA content, although differences between groups were apparent at completion of yolk absorption. Larvae held at $2{ }^{\circ} \mathrm{C}$ never fed. Increased mortality in this group began shortly before hatching and continued until complete mortality occurred on Day 21 . Larvae held at $5^{\circ} \mathrm{C}$ began feeding on the day of completion of yolk absorption. Larvae held at 7 and $10^{\circ} \mathrm{C}$ began feeding 1 and $2 \mathrm{~d}$ after yolk absorption, respectively. The poor condition of first feeding larvae at $10^{\circ} \mathrm{C}$ was indicated by their low RNA content and low RNA-DNA ratio. A positive linear relation between RNADNA ratio and growth rate was observed at 5,7 , and $10^{\circ} \mathrm{C}$. The effect of temperature on the RNA-DNA ratio-growth relation is described
\end{abstract}

\section{INTRODUCTION}

The early life history stages of fish have been identified as the most susceptible to environmental stress both natural and anthropogenic (e.g. Rosenthal and Alderdice, 1976). Mortality is greatest and most variable from year to year during the embryonic and larval phases and it is thought that the size of a year class is determined during this period. Studies of larval marine fishes, although essential to our understanding of the dynamics of fish populations, are hampered by several methodological problems. For example, there is no single generally accepted method for estimation of larval condition, and larval growth rate is difficult to estimate in the field. While predation and starvation have been proposed as major causes of larval mortality (Hunter, 1976), even a rough partitioning of total larval mortality between the two generally is not possible. The major predators of most species of larval fish have not been identified and there are few reports of finding starved larvae at sea.

We have proposed using the ratio of ribonucleic acid to deoxyribonucleic acid (RNA-DNA ratio) in larval fish as an indicator of both condition and growth rate (Buckley, 1979, 1980, 1981). Since larvae grow exponentially, condition and growth rate are closely associated. We have shown that the RNA-DNA ratio is very sensitive to changes in feeding levels in larval winter flounder Pseudopleuronectes americanus and larval cod Gadus morhua and therefore is useful for the diagnosis of the starving condition. Cod larvae held at higher plankton densities had higher RNA-DNA ratios and faster growth rates than larvae held at lower plankton densities (Buckley, 1979).

Since temperature, after food availability, appears to have the greatest role in controlling growth rate in larval fish, the present study was undertaken to determine the effect of temperature on the RNA-DNA ratio and the relationship between RNA-DNA ratio and growth rate in larval winter flounder. Also by examining the levels of selected classes of biomolecules during critical points in the life history of winter flounder we hoped to gain some additional insight into the

\footnotetext{
- This study is MARMAP Contribution MED/NEFC 81-4
} 
effects of temperature on the changeover from endogenous to exogenous food supplies. This study was conducted as part of the MARMAP program of the National Marine Fisheries Service (Sherman, 1980). It was undertaken as a contribution to understanding the causes of variability in the abundance of fish stocks off the northeast coast of the United States.

\section{MATERIALS AND METHODS}

Adult Pseudopleuronectes americanus were caught by trawl net off Rhode Island, USA, and kept in a 1,9001 aquarium. Eggs were obtained, fertilized and incubated by methods previously described (Smigielski, 1975). All eggs used in the present study were obtained from a single female that spawned at a water temperature of $2{ }^{\circ} \mathrm{C}$ without hormone induction. Embryos were acclimated to experimental temperatures at the rate of $2 \mathrm{C}^{\circ} \mathrm{d}^{-1}$. Groups of ca. 1,000 embryos were incubated at $10,7,5$, and $2{ }^{\circ} \mathrm{C}$ in 38-1 black all-glass aquaria. Larvae were fed live zooplankton collected in the Narragansett Bay area after sieving to select the appropriate size fraction. Plankton densities were adjusted daily to greater than 2 plankters $\mathrm{ml}^{-1}$. The diet consisted mainly of rotifers and copepod nauplii and copepodites.
All samples for biochemical analysis were run in triplicate. On the day of $50 \%$ hatch both larvae and unhatched embryos were sampled. Forty embryos or larvae were pooled per sample through Day 14 after hatch. Thereafter, sufficient larvae were pooled to give a sample dry weight of about $1 \mathrm{mg}$. Eggs and larvae were homogenized in $2 \mathrm{ml}$ of icecold water. Protein was determined on duplicate 0.1 or $0.05 \mathrm{ml}$ samples of homogenate using a modification of the Lowry method (Hartree, 1972). RNA and DNA were extracted and partially purified from $1.4 \mathrm{ml}$ of homogenate using a modification of the Schmidt-Thannhauser method (Munro and Fleck, 1966) adapted for the microquantities present in larval fish and eggs (Buckley, 1979).

The protein growth coefficient (Gp) expressed as the percent change in protein content per day was calculated from the slopes of the regression equations describing the relationship between the natural logarithm of the protein content $\left(\mu \mathrm{g} \mathrm{larvae}^{-1}\right)$ (dependent variable) and larval age (d). The instantaneous protein growth rate (Gpi) was calculated using the formula:

$$
\mathrm{Gpi}=\frac{1 n W_{\mathrm{t}_{2}}-1 n W_{t_{1}}}{t_{2}-t_{1}} \times 100
$$

where $W=$ weight in $\mu g_{i} t=$ age in $\mathrm{d}$.

Table 1. Pseudopleuronectes americanus. Standard length, protein, RNA and DNA content of eggs and larvae at hatching, completion of yolk absorption and first feeding *

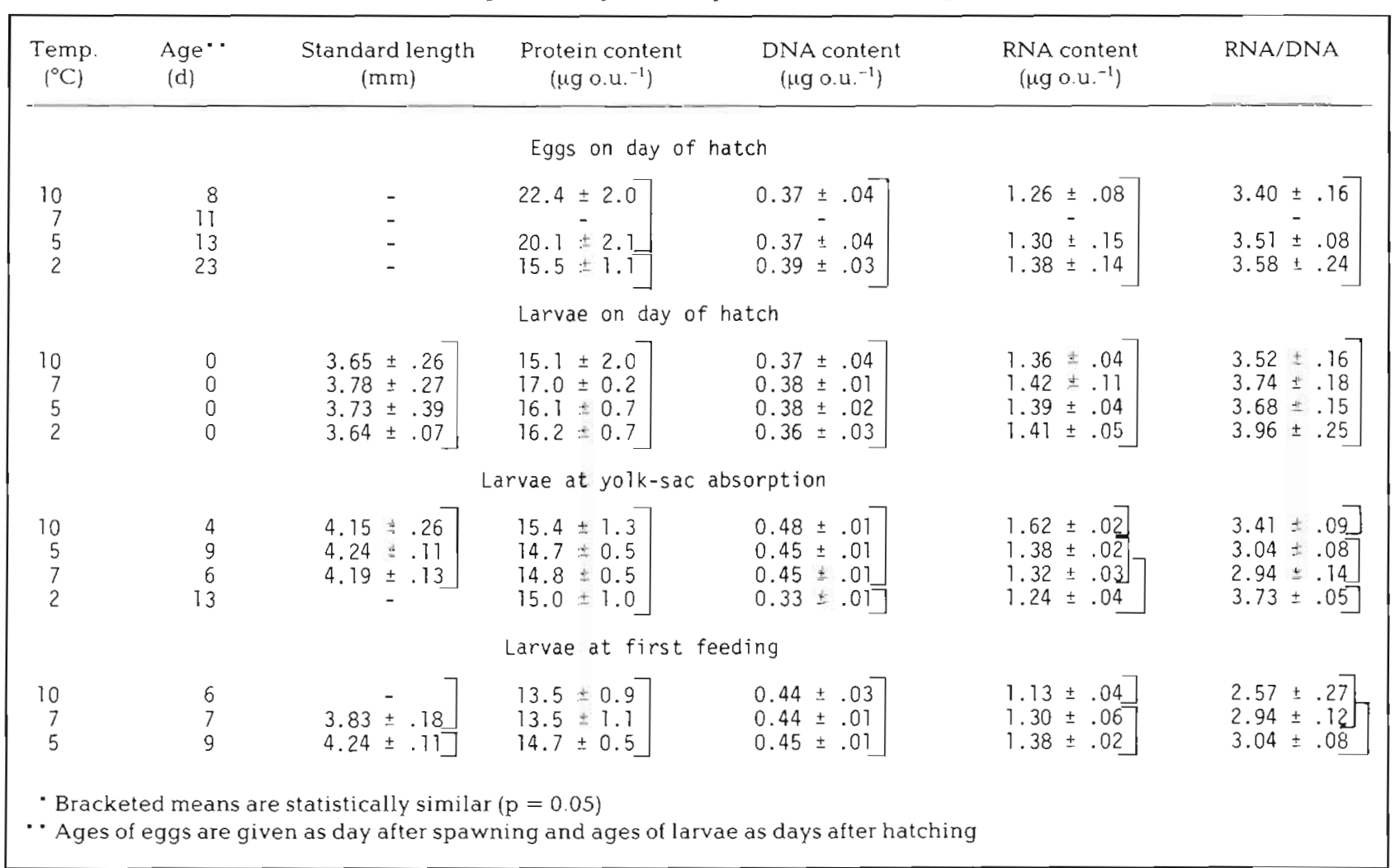




\section{RESULTS}

The period from fertilization to $50 \%$ hatch ranged from $8 \mathrm{~d}$ at $10^{\circ} \mathrm{C}$ to $23 \mathrm{~d}$ at $2{ }^{\circ} \mathrm{C}$ (Table 1). Survival from fertilization to hatching, although not strictly quantitated, appeared to be similar at temperatures between 10 and $5^{\circ} \mathrm{C}$ and somewhat lower at $2^{\circ} \mathrm{C}$. No significant difference in DNA content, RNA content, or RNA-DNA ratio of viable eggs was observed between temperature treatment groups at the time of $50 \%$ hatch (Table 1). Eggs held at $2{ }^{\circ} \mathrm{C}$ had a significantly lower protein content than eggs held at the higher temperatures. No significant difference in standard length, RNA-DNA ratio or RNA, DNA and protein content was observed in newly hatched larvae at any of the four

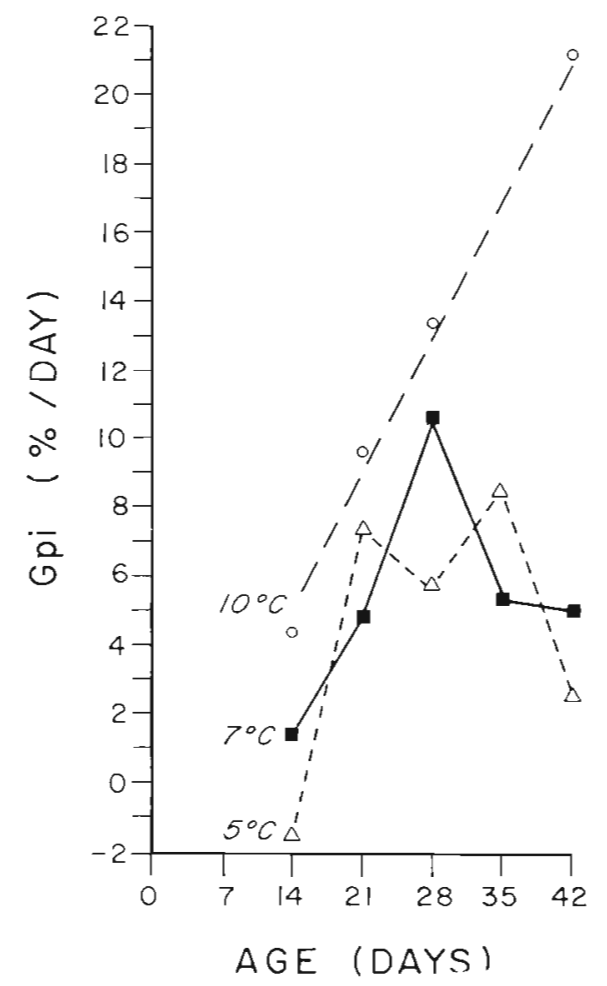

Fig. 1. Pseudopleuronectes americanus. Relation between age and growth rate of larvae at 5,7 , and $10^{\circ} \mathrm{C}$ temperatures between 10 and $2{ }^{\circ} \mathrm{C}$. Complete yolk-sac absorption occurred at $4,6,9$, and $13 \mathrm{~d}$ after hatching at $10,7,5$, and $2{ }^{\circ} \mathrm{C}$, respectively. At the completion of yolk absorption, larval DNA content was significantly lower at $2^{\circ} \mathrm{C}$ than at the higher temperatures. RNA content was lowest at $2{ }^{\circ} \mathrm{C}$ and highest at $10^{\circ} \mathrm{C}$. No significant difference was observed in standard length or protein content at completion of yolk absorption. Fifty percent of the larvae were first observed to have food in their guts 6,7 , and $9 \mathrm{~d}$ after hatching at 10,7, and $5{ }^{\circ} \mathrm{C}$, respectively, although food was made available shortly after hatching at all temperatures. Firstfeeding, therefore, occurred the same day as completion of yolk absorption at $5^{\circ} \mathrm{C}, 1 \mathrm{~d}$ after yolk absorption at $7{ }^{\circ} \mathrm{C}$, and $2 \mathrm{~d}$ after yolk absorption at $10^{\circ} \mathrm{C}$. Larvae held at $2{ }^{\circ} \mathrm{C}$ never established feeding. Mortality in this group reached $50 \%$ by Day 19 and $100 \%$ by Day 21. Protein and DNA content were similar at first feeding in all 3 groups that established feeding. RNA content and RNA-DNA ratio appeared to increase with decreasing temperature at first feeding (Table 1). Eighty percent mortality of larvae held at $10^{\circ} \mathrm{C}$ occurred $13 \mathrm{~d}$ after hatching.

Protein growth rates (Gp) were 13.7, 6.1, and $4.6 \%$

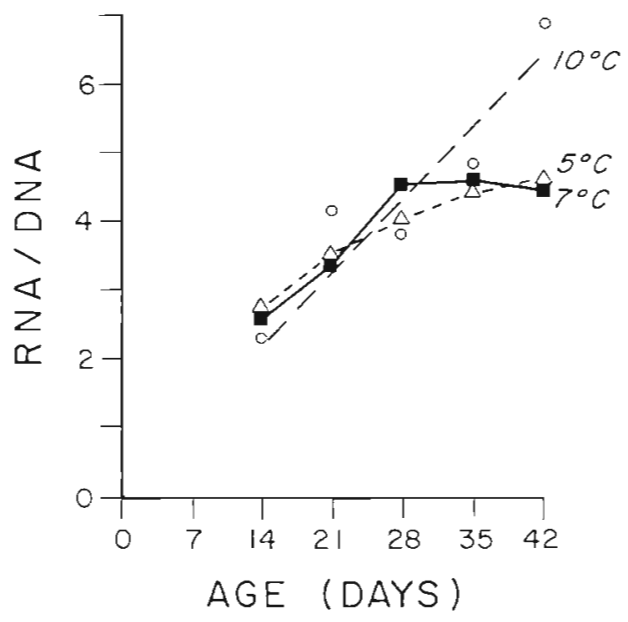

Fig. 2. Pseudopleuronectes americanus. Relation between age and RNA-DNA ratio of larvae at 5,7 , and $10{ }^{\circ} \mathrm{C}$

Table 2. Pseudopleuronectes americanus. Matrix showing correlations between rearing temperature, age, protein content and growth rate of larvae between 7 and $42 \mathrm{~d}$ after hatching. Given are correlation coefficients

\begin{tabular}{|c|c|c|c|c|c|}
\hline & Age & Temperature & Protein content & RNA-DNA ratio & Gpi \\
\hline Age & - & & & & \\
\hline Temperature & .03 & - & & & \\
\hline Protein content & $.50^{\circ}$ & $.43^{\circ}$ & - & & \\
\hline RNA-DNA ratio & $.78^{\circ}$ & $.28^{\circ}$ & $.73^{\circ}$ & - & \\
\hline Gpi & $46^{\circ}$ & $63^{\circ}$ & $.79^{\circ}$ & $.73^{\circ}$ & - \\
\hline \multicolumn{6}{|c|}{ - Indicates that pair is significantly correlated $(\mathrm{N}=50, \mathrm{p} \leq 0.05)$} \\
\hline
\end{tabular}


Table 3. Pseudopleuronectes americanus. Relations between temperature, age, protein content, RNA-DNA ratio and growth rate of larvae between 7 and $42 \mathrm{~d}$ after hatching reared at 3 temperatures

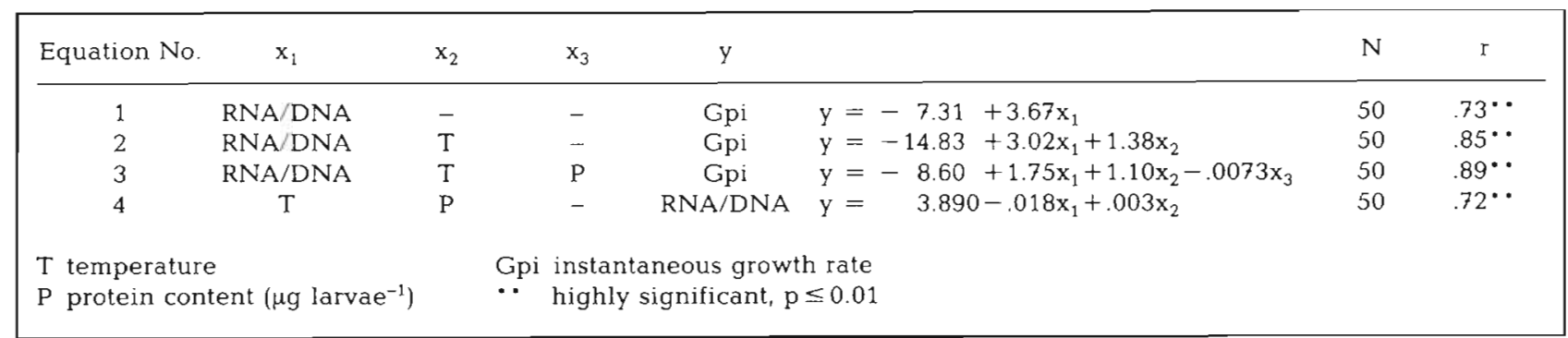

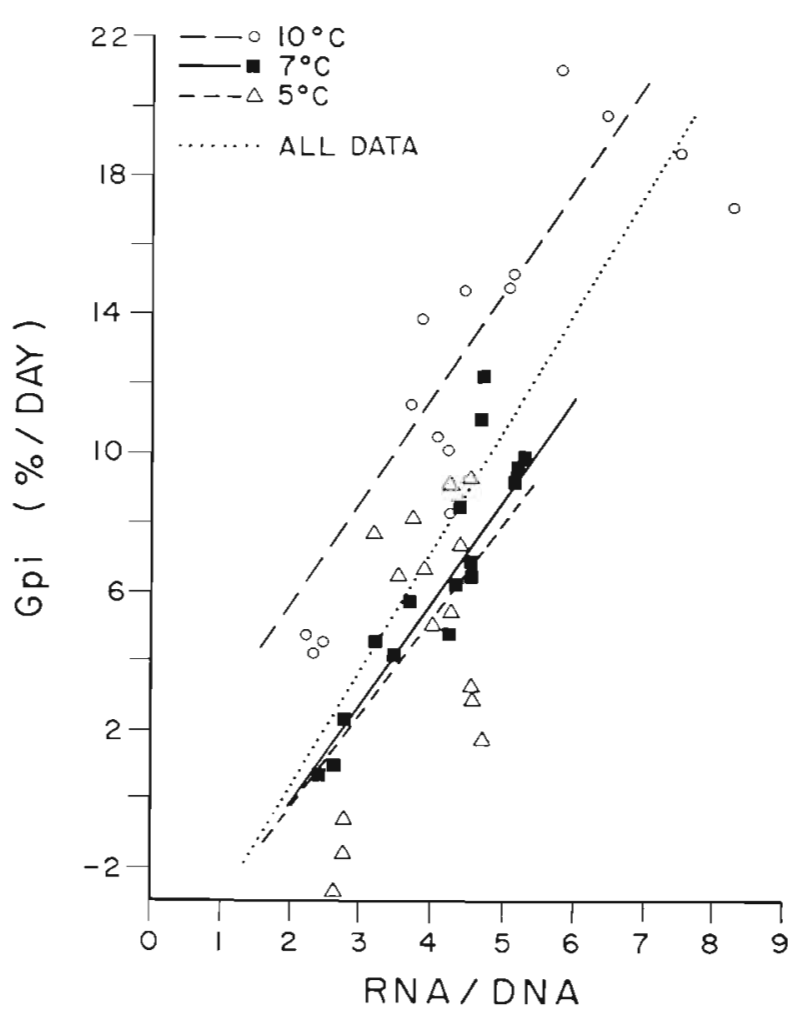

Fig. 3. Pseudopleuronectes americanus. Relation between RNA-DNA ratio and growth rate in larvae at 5,7 , and $10^{\circ} \mathrm{C}$

$\mathrm{d}^{-1}$ at 10,7 , and $5^{\circ} \mathrm{C}$, respectively. Food was available in excess at all temperatures. The instantaneous protein growth rate (Gpi) showed an initial increase at all 3 temperatures (Fig. 1). This increase was most dramatic and persistent at $10{ }^{\circ} \mathrm{C}$ where Gpi increased from a low of $4.4 \% \mathrm{~d}^{-1}$ during the $2 \mathrm{nd}$ wk after hatching to a high of $21 \% \mathrm{~d}^{-1}$ during the 5th and 6th wk. Gpi increased through the 4 th wk after hatching at $7^{\circ} \mathrm{C}$ and through the $3 \mathrm{rd}$ wk at $5^{\circ} \mathrm{C}$ (Fig. 1). The RNA-DNA ratio increased with age at all 3 temperatures (Fig. 2). Two-way analysis of variance indicated that both age and temperature as well as the interaction of these 2 factors had a significant effect ( $p \leq 0.05$ ) on the RNADNA ratio of larval winter flounder between 14 and $42 \mathrm{~d}$ after hatching. The mean RNA-DNA ratios during

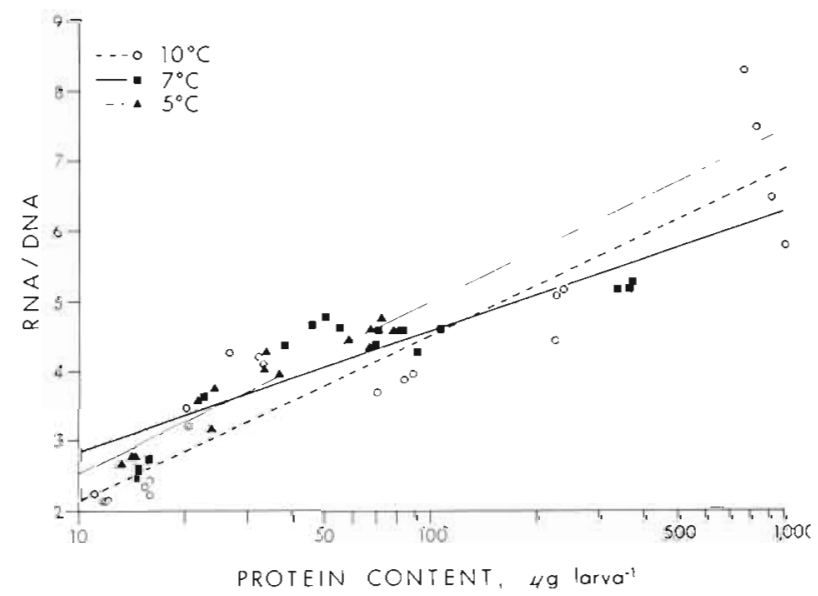

Fig. 4. Pseudopleuronectes americanus. Relation between size (protein content) and RNA-DNA ratio in larvae

this period were $4.9,3.9$, and 3.8 at 10,7 , and $5{ }^{\circ} \mathrm{C}$, respectively.

Correlations between RNA-DNA ratio, temperature, protein content, age and instantaneous protein growth rate are shown in Tables 2 and 3. Linear relationships were observed between larval RNA-DNA ratio and growth rate at all 3 temperatures (Fig. 3). The slopes of all 3 regression lines were not statistically different $(p \leq 0.05)$. The elevation ( $\mathrm{Y}$-intercept) of the line observed at $10^{\circ} \mathrm{C}$ was significantly greater than the elevations at either 5 or $7^{\circ} \mathrm{C}$. The elevation of the regression line observed at $7^{\circ} \mathrm{C}$ was greater than at $5^{\circ} \mathrm{C}$ but the difference was not significant $(p \leq 0.05)$. Linear relationships between the natural logarithm of larval protein content and RNA-DNA ratio were observed at all 3 temperatures (Fig. 4).

\section{DISCUSSION}

Winter flounder eggs fertilized in the laboratory at $2{ }^{\circ} \mathrm{C}$ hatched successfully at incubation temperatures between 2 and $10^{\circ} \mathrm{C}$. The larvae produced were not significantly different in standard length, RNA-DNA ratio, or RNA, DNA and protein content. This observa- 
tion is in apparent conflict with several reports of a general trend toward increasing size with decreasing incubation temperature (Sweet and Kinne, 1964; Linden et al., 1980). However, there are several reports of maximum size at hatching occurring at intermediate or higher temperatures within the range of tolerance (Alderdice and Forrester, 1968; Laurence and Rogers, 1976) and several reports that temperature had no significant effect on larval size at hatching (Johns et al., 1981; Laurence and Howell, 1981). Apparently the relationship between maximum larval size and incubation temperature is variable and may depend on the species and other environmental conditions. Increased mortality beginning just prior to hatching and ending in complete mortality on Day 21 was observed at $2{ }^{\circ} \mathrm{C}$. Laurence (1975) reported that larval winter flounder did not survive to metamorphosis at $2{ }^{\circ} \mathrm{C}$. While $2{ }^{\circ} \mathrm{C}$ is close to the temperature of maximum egg production $\left(3^{\circ} \mathrm{C}\right)$ and well within the range of temperatures $\left(-0.4^{\circ}\right.$ to $\left.5.2^{\circ} \mathrm{C}\right)$ in which spawning occurs in nature (Bigelow and Schroeder, 1953), $2^{\circ} \mathrm{C}$ is apparently below the temperature range for normal larval development. The observed decrease in DNA content between hatching and completion of yolk absorption at $2{ }^{\circ} \mathrm{C}$ is indicative of the failure of the developing system during this period. Since winter flounder are late winter spawners and given the long incubation period at lower temperatures, water temperature at hatching in nature generally is well above $2^{\circ} \mathrm{C}$.

Larvae hatched from eggs spawned at $2^{\circ} \mathrm{C}$ and incubated at 7 and $10^{\circ} \mathrm{C}$ developed normally until completion of yolk absorption when they apparently incurred an energy deficit until first feeding. First feeding occurred $1 \mathrm{~d}$ after complete yolk absorption at $7^{\circ} \mathrm{C}$ and $2 \mathrm{~d}$ after complete yolk absorption at $10^{\circ} \mathrm{C}$. The effects of this energy deficit were most apparent at $10^{\circ} \mathrm{C}$ where a decrease in RNA content between completion of yolk absorption and first feeding resulted in a low RNA content and, consequently, a low RNA-DNA ratio at first feeding (Table 1). The $80 \%$ mortality observed in larvae reared at $10{ }^{\circ} \mathrm{C}$ was probably also a result of this energy deficit. In a previous study, winter flounder larvae reared at $8^{\circ} \mathrm{C}$ and hatched from eggs spawned at $3.5^{\circ} \mathrm{C}$ completed yolk absorption $2 \mathrm{~d}$ prior to feeding initiation (Buckley, 1980). Whether or not winter flounder eggs spawned at higher temperatures would have sufficient energy reserves or a sufficiently high yolk conversion efficiency to develop to first feeding without incurring an energy deficit at these higher temperatures is not known. Lasker (1962) reported a deficiency of yolk energy, resorption of larval tissue and weight loss in larvae of the Pacific sardine Sardinops caerulea (Girard) prior to initiation of feeding. Laurence (1973) calculated energy budgets for larval tautog Tautoga onitis at 3 temperatures between 16 and $22{ }^{\circ} \mathrm{C}$ and found no indication of an actual deficiency of yolk energy prior to exogenous feeding capability. However, larvae reared at the lower range of spawning temperatures $\left(16^{\circ} \mathrm{C}\right)$ had the highest yolk conversion efficiency, were largest at completion of yolk absorption and did not appear to be as susceptible to a potential energy deficit in the event of limited planktonic prey distribution and abundance.

More important than the size of larvae at hatching or even at the completion of yolk-sac absorption is the size and condition of larvae at initiation of feeding. While some species initiate feeding prior to completion of yolk-sac absorption, others, such as winter flounder, initiate feeding at the time of completion of yolk-sac absorption or even later. Temperature may exert its greatest effect on larval development and subsequent recruitment by effecting the timing of completion of yolk-sac absorption and initiation of feeding, which must be regarded as two distinct events in larval development.

Winter flounder larvae that survived at $10^{\circ} \mathrm{C}$ grew at a faster rate than larvae reared at the lower temperatures. The steady increase in Gpi with age at $10^{\circ} \mathrm{C}$ may be a result of a gradual acclimation of the larvae to this higher temperature. In nature winter flounder would probably not experience this higher temperature until several weeks after hatching.

These observations suggest that growth and survival of winter flounder larvae are optimized by a gradual increase in water temperature during the embryonic and larval periods, thereby balancing the higher yolk conversion efficiency at lower temperatures $\left(2\right.$ to $5^{\circ} \mathrm{C}$ ) with the increased growth potential of older larvae at the higher temperatures $\left(7\right.$ to $10^{\circ} \mathrm{C}$ ). An extended period of low temperatures after spawning or a sudden rise in temperature prior to feeding initiation would be expected to have an adverse effect on growth and survival.

The direct linear relationship between RNA-DNA ratio and growth rate of larval winter flounder observed in this study is similar to the relationships observed for larval cod (Buckley, 1979), striped bass Morone saxatilis and summer flounder Paralichthys dentatus (Buckley, unpubl.). The addition of temperature as a second independent variable (Table 3) significantly reduced the residual mean square. The residual mean square was further reduced when protein content was added as a third independent variable (Table 3). Addition of larval age as an independent variable when RNA-DNA ratio and temperature are already in the regression equation removed very little of the unexplained variation in growth rate (Gpi). Our results with winter flounder (Figs. 3 and 4) suggest that the increased growth rate observed at higher temperatures is not accomplished or accompanied by an 
increase in the RNA-DNA ratio at the higher temperatures but rather by an increased growth rate at a given RNA-DNA ratio.

Although our laboratory studies have demonstrated that under certain conditions (i.e. constant plankton density or excess food) growth rate is related to age, temperature, and protein content (Table 2), the RNADNA ratio growth relation is the most useful for estimation of growth or condition since this relationship is valid under a wide range of environmental conditions. The utility of the RNA-DNA growth relation for estimation of growth rate, however, can be improved by introducing temperature as a second independent variable (Table 3).

\section{LITERATURE CITED}

Alderdice, D. F., Forrester, C. R. (1968). Some effects of salinity and temperature on early development and survival of the English sole (Parophrys ventulus). J. Fish. Res. Bd Can. 25: 495-521

Bigelow, H. B., Schroeder, W. C. (1953). Fishes of the Gulf of Maine, Bull. Fish Wildl. Serv. U.S. 53: 1-577

Buckley, L. J. (1979). Relationships between RNA-DNA ratio, prey density, and growth rate in Atlantic cod (Gadus morhua) larvae. J. Fish. Res. Bd Can. 36: 1497-1502

Buckley, L. J. (1980). Changes in Ribonucleic acid, Deoxyribonucleic acid, and protein content during ontogenesis in winter flounder, $P_{\text {seudopleuronectes americanus, and }}$ the effect of starvation. Fish. Bull. U.S. 77: 703-708

Buckley, L. J. (1981). Biochemical changes during ontogenesis of cod (Gadus morhua L.) and winter flounder (Pseudopleuronectes americanus) larvae. Rapp. P.-v. Réun. Cons. int. Explor. Mer 178: 547-552

Hartree, E. F. (1972). Determination of protein: a modification of the Lowry method that gives a linear photometric response. Analyt. Biochem. 48: 422-427

Hunter, J. R. (ed.) (1976). Report of a colloquium on larval fish mortality studies and their relation to fishery research. January 1975. U.S. Dep. Comm. NOAA Tech. Rep., NMFS Spec. Sci. Rep. (Fish.) 395: 1-5

Johns, D. M., Howell, W. H., Klein-MacPhee, G. (1981). Yolk utilization and growth to yolk-sac absorption in summer flounder (Paralichthys dentatus) larvae at constant and cyclic temperatures. Mar. Biol. 63: 301-308

Lasker, R. (1962). Efficiency and rate of yolk utilization by developing embryos and larvae of the Pacific sardine, Sardinops caerulea (Girard). J. Fish. Res. Bd Can. 19. $867-875$

Laurence, G. C. (1973). Influence of temperature on energy utilization of embryonic and prolarval tautog, Tautoga onitis. J. Fish. Res. Bd Can. 30: 435-442

Laurence, G. C. (1975). Laboratory growth and metabolism of winter flounder, Pseudopleuronectes americanus, from hatching through metamorphosis at three temperatures. Mar. Biol. 32: 223-229

Laurence, G. C., Howell, W. H. (1981). Embryology and influence of temperature and salinity on early development and survival of yellowtail flounder Limanda ferruginea. Mar. Ecol. Prog. Ser. 6: 11-18

Laurence, G. C., Rogers, C. A. (1976). Effects of temperature and salinity on comparative embryo development and mortality of Atlantic cod (Gadus morhua L.) and haddock (Melanogrammus aeglefinus [L.]). J. Cons. int. Explor. Mer 36: 20-228

Linden, O., Laughlin, R. Jr., Sharp, J. R., Neff, J. M. (1980) The combined effect of salinity, temperature and oil on the growth pattern of embryos of the killifish, Fundulus heteroclitus Walbaum. Mar. env. Res. 3: 129-144

Munro, H. N., Fleck, A. (1966). The detection of nucleic acids. In: Glick, D. (ed.) Methods of biochemical analysis, Vol. 17. Interscience Publishers, New York, pp. 113-176

Rosenthal, H., Alderdice, D. F. (1976). Sublethal effects of environmental stressors, natural and pollutional, on marine fish eggs and larvae. J. Fish. Res. Bd Can. 33: $2047-2065$

Sherman, K. (1980). MARMAP, a fisheries ecosystem study in the NW Atlantic: fluctuations in ichthyoplankton-zooplankton components and their potential for impact on the system. In: Diemer, F. P., Vernberg, F. J., Mirkes, D. Z. (eds.) Advanced concepts in ocean measurements for marine biology. Belle W. Baruch Institute for Marine Biology and Coastal Research, University of South Carolina Press, pp. 9-37

Smigielski, A. S. (1975). Hormonal-induced ovulation of the winter flounder, Pseudopleuronectes americanus. Fish. Bull. U.S. 73: $431-438$

Sweet, J. G., Kinne, O. (1964). The effects of various temperature-salinity combinations on the body form of newly hatched Cyprinidon macularis (Teleostei). Helgoländer wiss. Meeresunters. 11: 49-69 